\title{
Relationship among Entomosporium severity, defoliation, and vegetative-reproductive variables in pear in Brazil
}

\author{
Amauri Bogo(1), Mayra Juline Gonçalves( ${ }^{(1)}$, Rosa Maria Valdebenito Sanhueza ${ }^{(2)}$, Leo Rufato(1), \\ Ricardo Trezzi Casa ${ }^{(1)}$, Betina Pereira de Bem ${ }^{(1)}$ and Fabio Nascimento da Silva(1)
}

\begin{abstract}
(1)Universidade do Estado de Santa Catarina, Programa de Pós-Graduação em Produção Vegetal, Avenida Luiz Camões, no 2.090, Conta Dinheiro, CEP 88520-000 Lages, SC, Brazil. E-mail: amauri.bogo@udesc.br, mayra.juline@hotmail.com, leo.rufato@udesc.br, ricardo.casa@udesc.br, betadebem@yahoo.com.br, fabio.silva@udesc.br (2)Proterra Engenharia Agronômica Ltda., BR 116, no 7.320, Sala 02, Fátima, CEP 95200-000 Vacaria, RS, Brazil. E-mail: rosamaria@cipnet.com.br
\end{abstract}

\begin{abstract}
The objective of this work was to evaluate the relationship among Entomosporium severity, defoliation, and vegetative-reproductive variables of three European pear cultivars in Southern Brazil. The Packham's Triumph, Abate Fetel, and Williams pear cultivars were assessed regarding Entomosporium severity, defoliation, and natural leaf fall every two weeks, from the appearance of the first symptoms at the beginning of January until the end of April, during the 2012/2013 and 2013/2014 crop seasons. The vegetative and reproductive variables were evaluated in July, during the dormant period. Data on Entomosporium severity were integrated over time and converted into the area under the disease progress curve (AUDPC). The coefficient of determination $\left(\mathrm{R}^{2}\right)$ of the linear regression of Entomosporium severity versus defoliation was significant for all studied cultivars and crop seasons. Defoliation in trees affected by Entomosporium was significantly higher than natural leaf fall in the control trees protected by fungicides. A negative correlation was observed among defoliation, branch fertility index, and plant height, indicating that the higher the defoliation, the lower the development of the vegetative and reproductive variables plant height and vigor. Entomosporium severity differed significantly among cultivars when the AUDPC was considered the differentiating epidemiological variable. The Abate Fetel and Williams pear cultivars are the most susceptible and resistant to Entomosporium, respectively.
\end{abstract}

Index terms: Entomosporium mespili, Pyrus communis, area under the disease progress curve, natural leaf fall.

\section{Relação entre severidade da entomosporiose, desfolha e variáveis vegetativas-reprodutivas em pereira no Brasil}

\begin{abstract}
Resumo - O objetivo deste trabalho foi avaliar a relação entre severidade da entomosporiose, desfolha e variáveis vegetativas-reprodutivas de três cultivares de pera europeia no Sul do Brasil. As cultivares de pera Packham's Triumph, Abate Fetel $\mathrm{e}$ William foram avaliadas quanto à severidade da entomosporiose, à desfolha e à queda natural de folhas a cada 15 dias, desde o surgimento dos primeiros sintomas no início de janeiro até o fim de abril, durante as safras de 2012/2013 e 2013/2014. As variáveis vegetativas e reprodutivas foram analisadas em julho, durante o período de dormência das plantas. Os dados da severidade da entomosporiose foram integrados ao longo do tempo e convertidos para área abaixo da curva de progresso da doença (AACPD). O coeficiente de determinação $\left(\mathrm{R}^{2}\right)$ da regressão linear da severidade da entomosporiose versus desfolha foi significativo para todas as cultivares e as safras estudadas. A desfolha em plantas infectadas pela entomosporiose foi significativamente maior do que a queda natural de folhas nas plantas-controle tratadas com fungicidas. Houve correlação negativa entre desfolha, índice de fertilidade dos ramos e altura de plantas, o que indica que, quanto maior a desfolha, menor é o desenvolvimento das variáveis vegetativas e reprodutivas altura de planta e vigor. A severidade da entomosporiose diferiu significativamente entre as cultivares avaliadas quando a AACPD foi considerada como a variável epidemiológica diferenciadora. As cultivares de pera Abate Fetel e Williams são as mais suscetível e resistente à entomosporiose, respectivamente.
\end{abstract}

Termos para indexação: Entomosporium mespili, Pyrus communis, área abaixo da curva de progresso da doença, queda natural das folhas.

\section{Introduction}

Brazilian pear (Pyrus communis L.) production was approximately 15 thousand tons in 2015/2016 (IBGE, 2017b). Associated with per capita consumption, there is a high potential for pear culture expansion, especially in Southern Brazil where climatic and soil conditions are favorable. In this region, the pear crop is an excellent alternative for temperate climate fruit diversification (IBGE, 2017a). However, its production
Pesq. agropec. bras., Brasília, v.53, n.8, p.892-899, Aug. 2018 DOI: 10.1590/S0100-204X2018000800003 Creative Commons Attribution 4.0 International License 
can be affected by phytosanitary problems, such as Entomosporium, which is one of the most important diseases of pear worldwide (Bell \& Van Der Zwet, 2005; Fioravanço, 2007).

Entomosporium is caused by the fungus Diplocarpon mespili (Sorauer) B. Sutton (anamorph: Entomosporium mespili (DC.) Sacc. and is distributed throughout temperate and tropics zones in Central America and Africa, spreading with high intensity to all Europe, Australia, Canada, USA, Paraguay, and Brazil (Gonçalves et al., 2013, 2014). Specifically in Southern Brazil, Entomosporium is a prominent disease that can drastically increase during plant growth, depending on microclimate, cultivar susceptibility, and primary inoculum liberation (Nunes et al., 2016), often causing early defoliation.

Severe defoliation is the main factor affecting yield reduction in Southern Brazil. It occurs during summer, reducing plant photosynthetic capacity and number of flower buds, besides weakening the trees by decreasing their vigor and yield (Bell \& Van der Zwet, 2005; Gonçalves et al., 2013; Nunes et al., 2016). Despite extensive disease protection measures, especially with fungicides, defoliation is still common in the region, which makes it extremely difficult to keep leaves on trees up to the time of natural defoliation. It should be noted that defoliation is characteristically worse in the lower half of the plant canopy and, by harvest time, leaves may remain only at the top of the plants (Gonçalves et al., 2013, 2014).

Defoliation has contributed to the lack of success of European pear production in Southern Brazil and is a cause of concern among most farmers due to its effects on plant phenology, quality of buds, effective fruit set, and fruit quality. However, there are no known studies that establish a correlation between the defoliation caused by Entomosporium and vegetative and reproductive variables, or that stipulate an economic damage threshold.

The objective of this work was to evaluate the relationship among Entomosporium severity, defoliation, and vegetative-reproductive variables of three European pear cultivars in Southern Brazil.

\section{Materials and Methods}

Three 12-year-old European pear cultivars - Abate Fetel, Packham's Triumph, and Williams - grafted on the Adams quince (Cydonia oblonga Mill.) rootstock were evaluated. The experiment was conducted in an orchard located in the municipality of Vacaria, in the state of Rio Grande do Sul, Southern Brazil (2830'44"S, $50^{\circ} 56^{\prime} 02^{\prime \prime} \mathrm{W}$, at an altitude of $971 \mathrm{~m}$ above sea level), during the 2012/2013 and 2013/2014 crop seasons. The climate of the region is humid mesothermal $(\mathrm{Cfb})$, according to Köppen's classification, and represents the climatic conditions of most pear producing regions in Southern Brazil. The soil is classified as an Argissolo Amarelo distrófico (Santos et al., 2013), i.e., a Typic Kandiustult. Data on rainfall, relative humidity, and minimum, average, and maximum temperatures during the experimental period were obtained from the weather station of Instituto Nacional de Metereologia (Inmet), located at Empresa Brasileira de Pesquisa Agropecuária (Embrapa), at an approximate distance of $2 \mathrm{~km}$ (Figure 1).

The evaluated pear plants were approximately 2.5- $\mathrm{m}$ tall and were trained to a slender spindle in a high-density plantation with a spacing of $3.0 \times 1.0 \mathrm{~m}$. All three cultivars are known to be susceptible to E. mespili, and the disease had been present in the orchard during previous years.

The inoculum of E. mespili was diagnosed by indirect symptoms: tiny, circular, bright red spots on both the upper and lower surfaces of young expanding leaves; and ash-brown to light-grey centers with a deep-red to maroon border on mature leaves. Under microscope examination, four-celled conidia, with a distinctive insect-like appearance typical of E. mespili, were identified.

The trial was set up as a randomized complete block design, with three blocks and two treatments: with (control) and without fungicide application. Individual plots within each block consisted of five rows of ten trees. Data were collected from the central plants in each row, and the remaining plants were kept as guards. The control was used to determine natural leaf fall and was maintained at a distance of five rows from the non-treated area, in order to prevent fungicide drift. The area treated with fungicide was sprayed from September to April, 10-12 times during the 2012/2013 and 2013/2014 crop seasons, with the commercially recommended rates of: mancozeb, i.e., $800 \mathrm{~mL} \mathrm{~L}^{-1}$ dithiocarbamate (Dithane NT, Dow AgroSciences Industrial Ltda., São Paulo, SP, Brazil); and thiophanate-methyl, i.e., $700 \mathrm{~mL} \mathrm{~L}^{-1}$ benzimidazole (Cercobin 700 WP, Iharabras S.A. Indústrias Químicas, 
Sorocaba, SP, Brazil). The areas with and without fungicide application were compared using the means obtained in both crop seasons.

Ten plants of each cultivar were selected from the areas treated or not with fungicides during 2012/2013 and 2013/2014, and four medium-height branches per plant were labeled and assessed for: natural leaf fall in the area with fungicide application; and Entomosporium severity and defoliation in the non-treated area. Entomosporium severity, defoliation, and natural leaf fall were evaluated every two weeks, starting when the first symptoms appeared at beginning of January to the end of April, using 25 labeled young leaves per each of the four medium-height branches. The leaves on the labeled branches were counted from the distal to the proximal branch points. The percentages of defoliation and natural leaf fall were calculated at five evaluation times by dividing the number of leaves per branch by the initial number of leaves per branch. Entomosporium severity was determined using the same branches, at the same evaluation times, but on fewer leaves at each subsequent assessment time due to defoliation. For this evaluation, leaves were assigned infection classes according to Nunes \& Alves (2012), and an average Entomosporium severity score was calculated for each plant at each evaluation time. Data on Entomosporium severity were integrated over time and converted into the area under the disease progress curve (AUDPC)

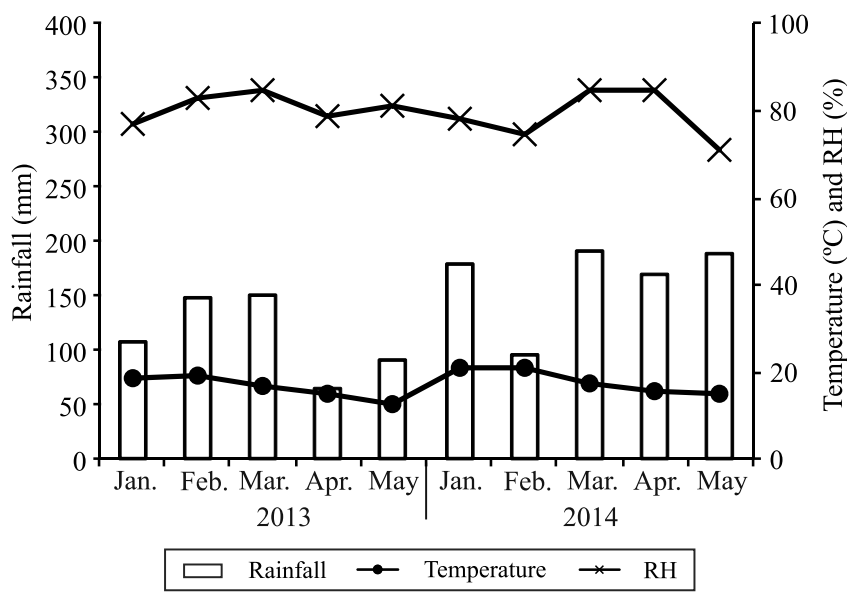

Figure 1. Average monthly accumulated rainfall, relative humidity $(\mathrm{RH})$, and average temperature in the municipality of Vacaria, in the state of Rio Grande do Sul, Southern Brazil, during the evaluation of Entomosporium severity in the 2012/2013 and 2013/2014 crop seasons. according to Campbell \& Madden (1990). The nonnormally distributed data of Entomosporium severity and defoliation were subjected to the Shapiro-Wilk and Bartlett tests, both at 5\% probability, to verify the normality of residuals and homogeneity of variance, respectively. The SAS software, version 9.1 (SAS Institute, Inc., Cary, NC, USA), was used for all data analyses.

The vegetative and reproductive variables trunk diameter $(\mathrm{cm})$, plant height $(\mathrm{m})$, canopy volume $\left(\mathrm{m}^{3}\right)$, and branch fertility index (bud per centimeter) were evaluated twice, in July 2013 and 2014, when the plants were dormant. For this, the labeled plants in the area without fungicide application were used. Plant trunks were marked $5 \mathrm{~cm}$ above the ground using plastic ink, and trunk diameters were measured with a digital caliper. Plant height was measured from the ground to the tip of the plants using a topographic ruler. Before pruning, canopy width $(\mathrm{m})$ and thickness $(\mathrm{m})$ were measured from the point of the insertion of the first trunk branch to the tip of the canopy using a measuring tape and topographic ruler. The canopy measures were then used to calculate the canopy average volume according to Uresk et al. (1977). The branch fertility index was considered as the relationship between the length $(\mathrm{m})$ and the number of vegetative and floral buds on two labeled branches of each selected plant; a measuring tape was also used to obtain length.

The correlations among Entomosporium severity, defoliation, and vegetative and reproductive variables were statistically analyzed using Pearson's correlation and were compared by Student's t-test, at 5\% probability (Madden et al., 2007). Data were evaluated by the analysis of variance (Duncan's test) using the Sisvar software, version 4.2 (Ferreira, 2003), also at $5 \%$ probability.

\section{Results and Discussion}

Irrigation was usually unnecessary during the experimental period because rainfall was regularly distributed throughout the year, with an annual average between 1,620 and 1,750 $\mathrm{mm}$. The average air temperature and relative humidity were similar in both crop seasons: $16^{\circ} \mathrm{C}$ and $82 \%$, respectively, in $2012 / 2013$, and $18^{\circ} \mathrm{C}$ and $81 \%$, respectively, in 2013/2014 (Figure 1). Within these temperature and relative humidity intervals, the expression of symptoms 
varies according to the development of the pathogen (Gonçalves, 2013; Nunes et al., 2016). In the present study, the initial symptoms of Entomosporium under natural infection processes were observed during the first half and at the beginning of January in the 2012/2013 and 2013/2014 crop seasons, respectively. Nunes et al. (2016) found that the conidial germination of $E$. mespili occurred within a 6-hour incubation period at $20^{\circ} \mathrm{C}$ and a 6 -hour foliar wetness; the latter is an important epidemiological factor for the development of diseases because most of the pathogens require free water on leaf surface to germinate on and penetrate into the host plant.

The differences between the two crop seasons regarding the date when the first symptoms appeared and Entomosporium severity can be attributed to one or more unfavorable climatic factors related to the development of the disease, including: minimum, average, and maximum temperatures; relative humidity; and rainfall (Figure 1). Entomosporium severity, for example, decreased from the 2012/2013 to the 2013/2014 crop season, probably due to the decrease in rainfall observed during February/ March of 2013/2014, compared with the same period of 2012/2013 (Figures 1 and 2). According to Bell \& Van der Zwet (2005) and Agrios (2005), factors such as cultivars, previous amounts of pathogen inocula, temperature, and humidity during the crop season could influence plant resistance or susceptibility.

All studied cultivars were shown to be susceptible to E. mespili infection, but at varying intensities (Figure 2 and Table 1). The same trend was observed by Gonçalves et al. $(2013,2014)$ when evaluating the effect of different combinations of rootstocks and cultivars. A possible explanation is the differentiation in some epidemiological variables according to the levels of Entomosporium severity; the slow growth of lesions and the late and low production of spores, for example, can affect the progress rate of the disease, reducing its damage (Agrios, 2005; Madden et al., 2007).

The highest Entomosporium severities were 21 and $14 \%$ for Abate Fetel, the most susceptible cultivar, during the 2012/2013 and 2013/2014 crop seasons, respectively (Figure 2); the inoculum pressure was lower in 2013/2014 probably due to the reduced rainfall in March. Although the two more susceptible cultivars, Abate Fetel and Packham's Triumph, differed greatly from the more resistant Williams in the 2012/2013 crop season, the difference between them was less obvious when inoculum pressure was reduced in 2013/2014 (Figure 2).

The $\mathrm{R}^{2}$ values obtained in the linear regression analyses of Entomosporium severity versus defoliation were significant $(p<0.05)$ for all three cultivars during both the 2012/2013 and 2013/2014 crop seasons (Figure 3 ). The significant $\mathrm{R}^{2}$ values showed the interference of E. mespili on defoliation during 2012/2013 and 2013/2014, and provided unprecedented
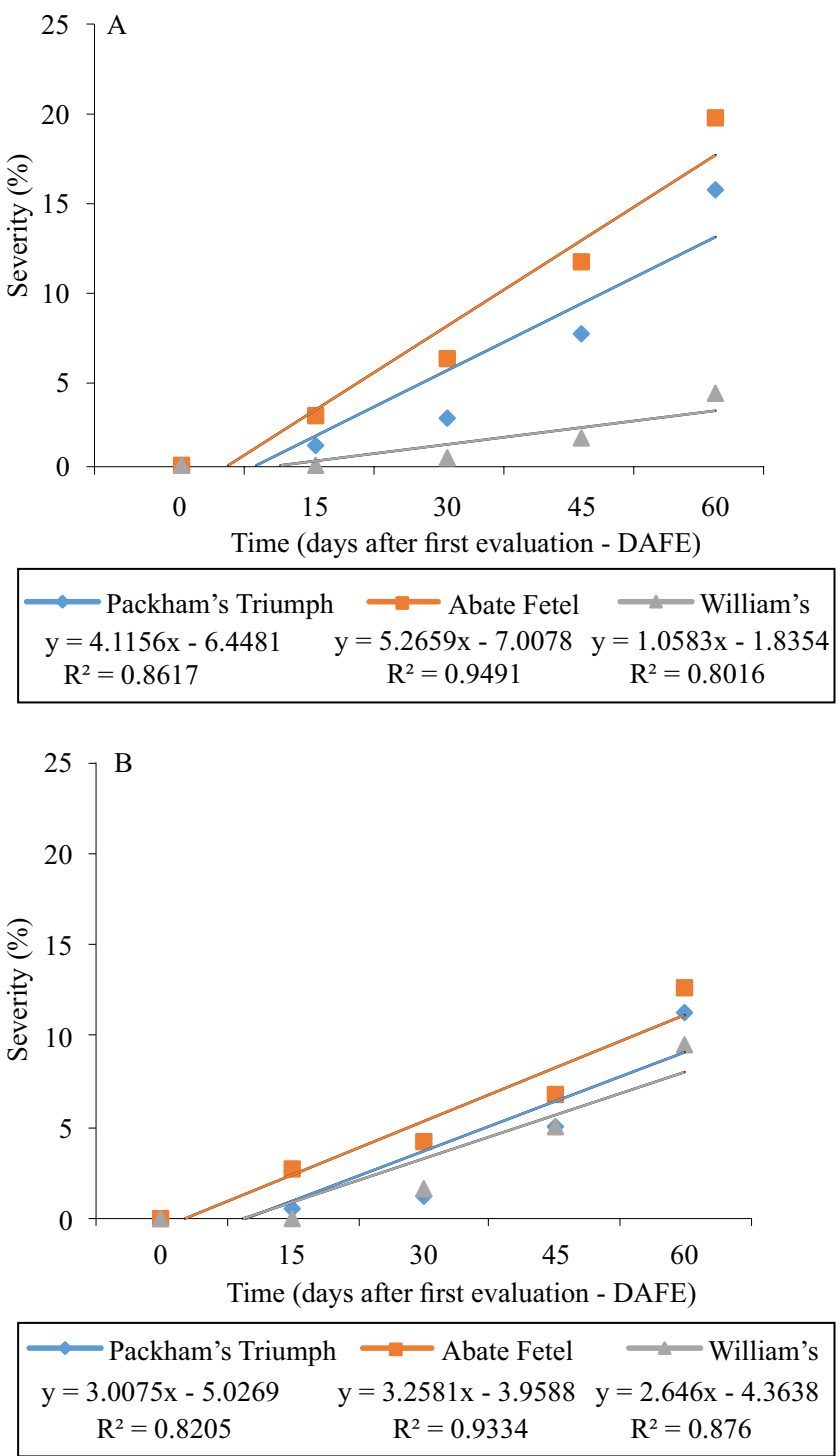

Figure 2. Entomosporium progress curves for the European pear (Pyrus communis) cultivars Packham's Triumph, Abate Fetel, and Williams during the 2012/2013 (A) and 2013/2014 (B) crop seasons. 
data for this E. mespili-pear pathosystem (Figure 3). This correlation and the $\mathrm{R}^{2}$ values of the Abate Fetel and Williams cultivars increased from 2012/2013 to 2013/2014 (Figure 3). The increment in the $\mathrm{R}^{2}$ values of these two cultivars was from 0.80 to 0.97 and from 0.65 to 0.88 , respectively. For the Packham's Triumph cultivar, Entomosporium severity and defoliation showed a positive correlation with the $\mathrm{R}^{2}$ values of
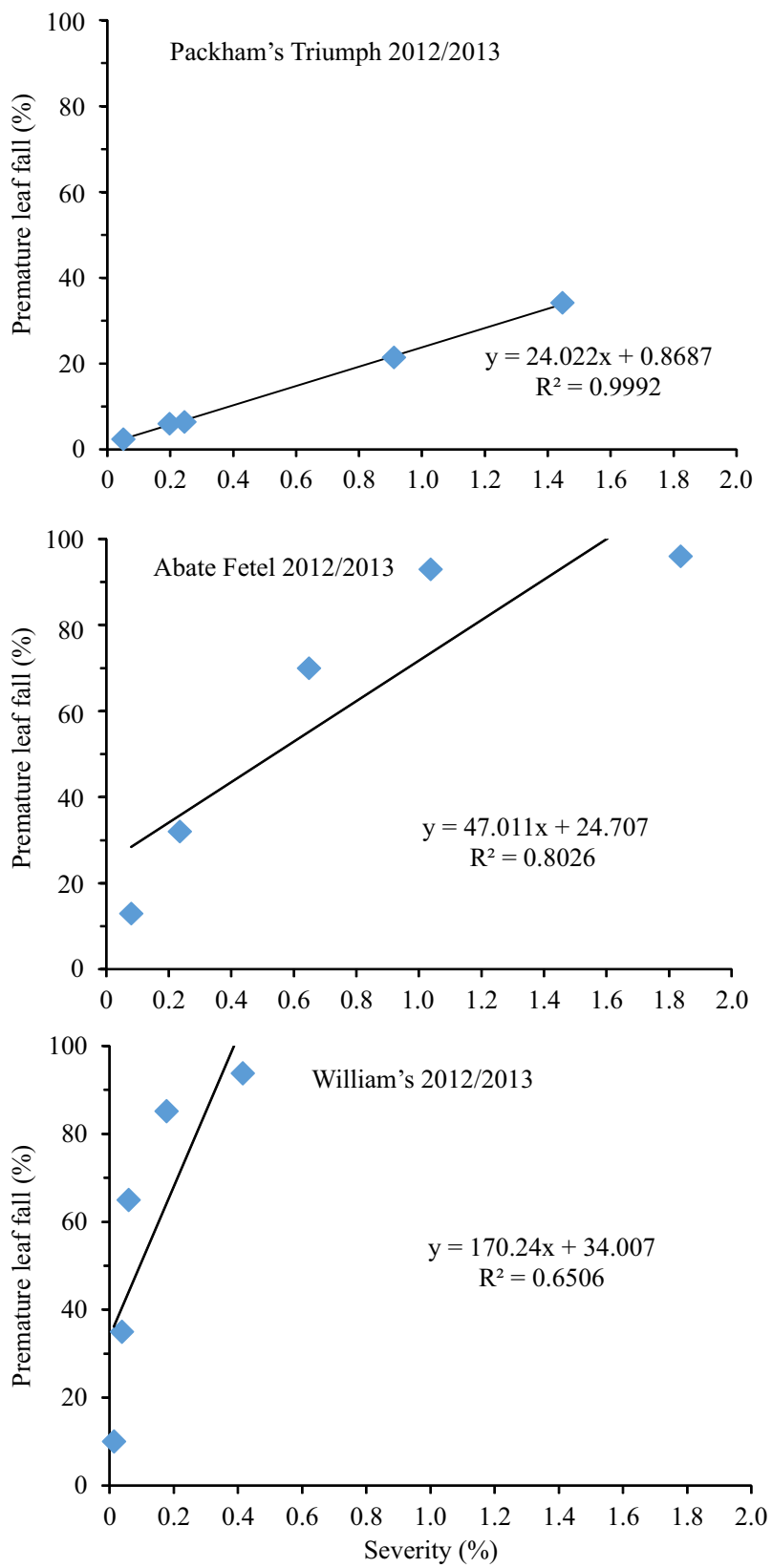

0.99 and 0.92 during the 2012/2013 and 2013/2014 crop seasons, respectively.

The AUDPC of Entomosporium among the three cultivars differed significantly during 2012/2013 and 2013/2014 (Tables 1 and 2). The Williams cultivar showed the lowest susceptibility to Entomosporium during both crop seasons (Figure 2 and Table 1), whereas Packham's Triumph and Abate Fetel were
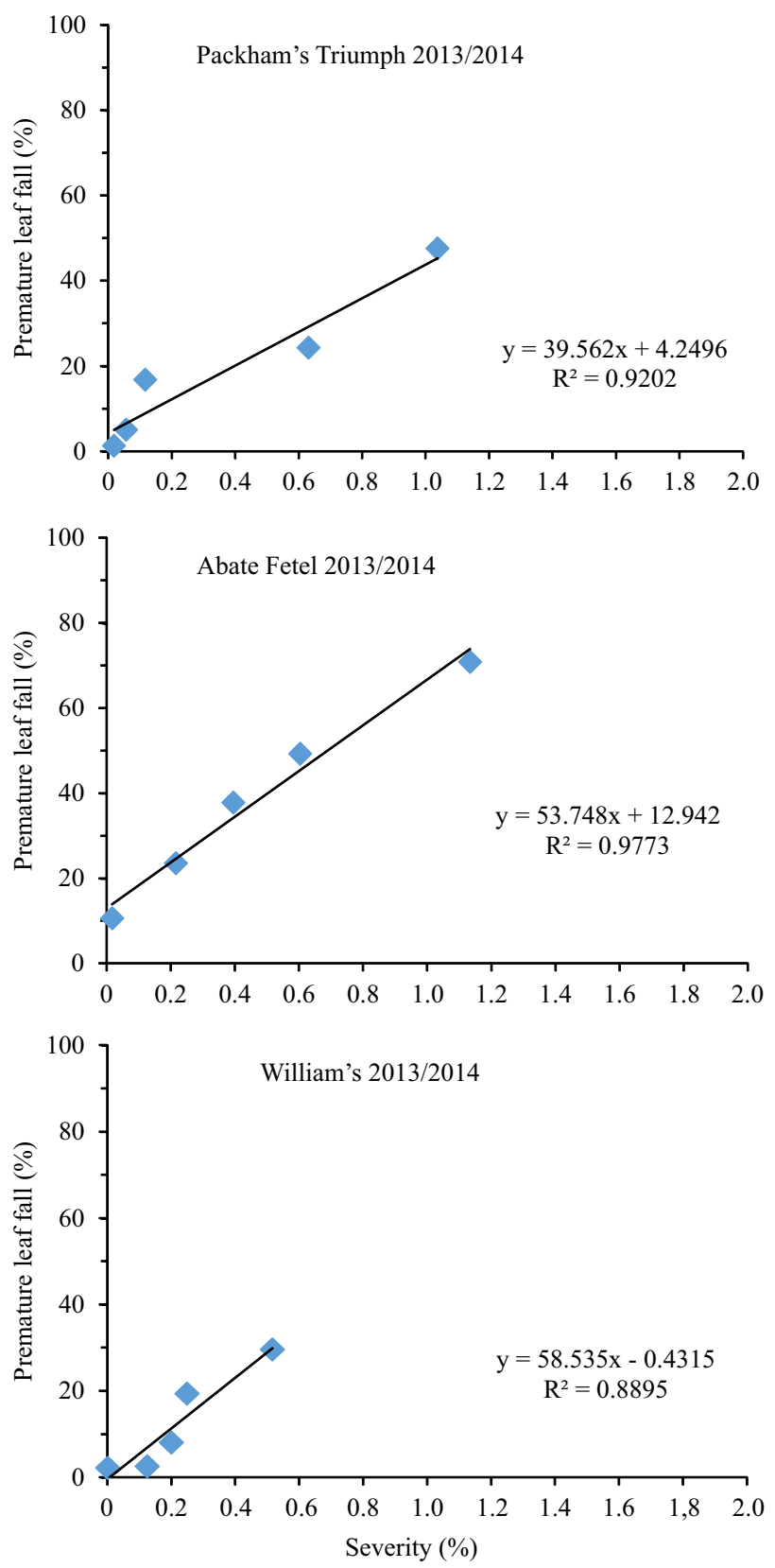

Figure 3. Relationship between Entomosporium severity and defoliation in the European pear (Pyrus communis) cultivars Packham's Triumph, Abate Fetel, and Williams during the 2012/2013 and 2013/2014 crops seasons. 
the most susceptible, despite differing significantly between 2012/2013 and 2013/2014. It should be pointed out that the use of genotypes with partial Entomosporium resistance can be useful in reducing fungicide application frequency, while still controlling early defoliation. In this case, the AUDPC is an important epidemiological parameter for comparing the resistance of cultivars, being higher for susceptible cultivars than for resistant ones.

The defoliation of the Abate Fetel and Williams cultivars occurred 3-4 and 5-6 weeks after the beginning of the epidemic in 2012/2013 and 2013/2014, respectively. In the areas without fungicide application, the onset of defoliation induced by Entomosporium started earlier and reached higher levels in the Abate Fetel and Williams cultivars, compared with Packham's Triumph, by the end of April in both crop seasons (Figure 3). In the fungicide-treated control plot, natural leaf fall was significantly lower by the end of April for all studied cultivars and crop seasons (Table 2). Natural leaf fall did not differ among cultivars, but defoliation was significantly greater in Abate Fetel and Packham's Triumph, which showed high Entomosporium severity, compared with Williams. While evaluating peach [Prunus persica (L.) Batsch] rust, Challiol et al. (2006) also found that defoliation was related to the increase in the severity of the disease.

There was a negative correlation, at $5 \%$ probability, between defoliation and the increase of vegetative and reproductive variables. This correlation was specifically observed among defoliation, branch fertility index, and plant height, indicating that the greater the defoliation, the lower the development of the vegetative and reproductive variables plant height and vigor (Table 3). This shows the need for preventive chemical or alternative disease control.

The less susceptible cultivar, Williams, had a significant increment in the development of canopy volume and branch fertility index during the 2012/2013 and 2013/2014 crop seasons (Table 1). However, regarding plant height, no significant difference was observed for this cultivar, whereas the greatest increments were obtained for Packham's Triumph and Abate Fetel during both 2012/2013 and 2013/2014. According to Agrios (2005), defoliation leads to a reduction in carbohydrate reserve levels and reduces root growth for the next crop season in woody plants. The authors suggested that the higher branch fertility index was correlated with the lower plant vegetative growth, subsequently improving the balance between the plant's vegetative and reproductive parts as a response to the lower ascending and descending translocated plant sap. The strong correlation between Entomosporium severity and defoliation means that it is possible that the severity of the disease affects branch fertility, deteriorating this balance.

The epidemic development of Entomosporium within the growth cycle of pear is determined by

Table 1. Vegetative and reproductive variables of the European pear (Pyrus communis) cultivars Packham's Triumph, Abate Fetel, and Williams during the 2012/2013 and 2013/2014 crop seasons ${ }^{(1)}$.

\begin{tabular}{|c|c|c|c|c|c|}
\hline Cultivar & $\mathrm{AUDPC}^{(2)}$ & $\begin{array}{l}\text { Trunk diameter } \\
(\mathrm{cm})\end{array}$ & $\begin{array}{l}\text { Canopy volume } \\
\left(\mathrm{m}^{3}\right)\end{array}$ & $\begin{array}{l}\text { Branch fertility } \\
\text { (bud per centimeter) }\end{array}$ & $\begin{array}{l}\text { Plant height } \\
\text { (m) }\end{array}$ \\
\hline & & \multicolumn{4}{|c|}{$2012 / 2013$ crop season } \\
\hline Packham's Triumph & $43.95 b$ & 5.53 & $1.36 \mathrm{~b}$ & $0.58 \mathrm{~b}$ & $2.51 \mathrm{a}$ \\
\hline Abate Fetel & $58.99 \mathrm{a}$ & $4.67^{\mathrm{ns}}$ & $1.11 \mathrm{~b}$ & $0.53 \mathrm{~b}$ & $2.51 \mathrm{a}$ \\
\hline Williams & $6.70 \mathrm{c}$ & 4.45 & $2.54 \mathrm{a}$ & $0.98 \mathrm{a}$ & $1.98 \mathrm{~b}$ \\
\hline \multirow[t]{2}{*}{ Coefficient of variation (\%) } & & 12.4 & 13.4 & 12.7 & 14.1 \\
\hline & & \multicolumn{4}{|c|}{ 2013/2014 crop season } \\
\hline Packham's Triumph & $28.07 \mathrm{a}$ & $6.03 \mathrm{a}$ & $0.66 b$ & $0.68 b$ & $2.80 \mathrm{a}$ \\
\hline Abate Fetel & $29.97 \mathrm{a}$ & $5.30 \mathrm{ab}$ & $1.29 \mathrm{~b}$ & $0.65 b$ & $3.00 \mathrm{a}$ \\
\hline Williams & $18.87 \mathrm{~b}$ & $4.23 b$ & $2.53 \mathrm{a}$ & $1.03 \mathrm{a}$ & $2.25 b$ \\
\hline Coefficient of variation (\%) & & 11.4 & 13.2 & 13.3 & 12.2 \\
\hline
\end{tabular}


the initial amount of the fungus and by how fast it increases, according to its apparent infection rate. In the present study, plants protected with fungicides suffered less leaf fall than those that were not and, consequently, showed high Entomosporium severity in

Table 2. Entomosporium severity and defoliation caused by the disease and natural leaf fall (control) in the European pear (Pyrus communis) cultivars Packham's Triumph, Abate Fetel, and Williams during the 2012/2013 and 2013/2014 crop seasons ${ }^{(1)}$.

\begin{tabular}{lccc}
\hline Cultivar & $\begin{array}{c}\text { Entomosporium } \\
\text { severity }{ }^{(2)}\end{array}$ & Defoliation $^{(3)}$ & Natural leaf fall $^{(3)}$ \\
\hline Packham's Triumph & $14.82 \mathrm{~b}$ & $0.55 \mathrm{Aa}$ & $0.79 \mathrm{Ba}$ \\
Abate Fetel & $19.80 \mathrm{a}$ & $0.50 \mathrm{Aa}$ & $0.64 \mathrm{Ba}$ \\
Williams & $5.45 \mathrm{c}$ & $0.31 \mathrm{Bb}$ & $0.76 \mathrm{Aa}$ \\
\hline
\end{tabular}

${ }^{(1)}$ Means followed by equal letters, uppercase in the rows and lowercase in the columns, do not differ significantly by the PLSD test, at $5 \%$ probability. (2) Maximum severity assigned by infection classes, according to Nunes \& Alves (2012). ${ }^{(3)}$ Proportion of fallen leaves estimated as the difference between the number of leaves per branch during each evaluation time and the initial leaves per branch.

Table 3. Pearson's correlations between defoliation and vegetative-reproductive variables for the European pear (Pyrus communis) cultivars Packham's (P.) Triumph, Abate Fetel, and Williams evaluated during the dormant period in July of the 2012/2013 and the 2013/2014 crop seasons.

\begin{tabular}{|c|c|c|c|c|c|}
\hline Cultivar & & Defoliation & $\begin{array}{c}\text { Trunk } \\
\text { diameter } \\
\text { (cm) }\end{array}$ & $\begin{array}{l}\text { Canopy } \\
\text { volume } \\
\left(\mathrm{m}^{3}\right)\end{array}$ & $\begin{array}{c}\text { Branch } \\
\text { fertility } \\
\text { (bud per } \\
\mathrm{cm} \text { ) }\end{array}$ \\
\hline P. Triumph & \multirow{3}{*}{$\begin{array}{l}\text { Trunk } \\
\text { diameter } \\
(\mathrm{cm})\end{array}$} & 0.53 & & & \\
\hline Abate Fetel & & 0.49 & & & \\
\hline Williams & & -0.33 & & & \\
\hline P. Triumph & \multirow{3}{*}{$\begin{array}{l}\text { Canopy } \\
\text { volume } \\
\left(\mathrm{m}^{3}\right)\end{array}$} & 0.50 & 0.48 & & \\
\hline Abate Fetel & & 0.09 & -0.43 & & \\
\hline Williams & & -0.08 & 0.63 & & \\
\hline P. Triumph & \multirow{3}{*}{$\begin{array}{l}\text { Branch } \\
\text { fertility } \\
\text { (bud per } \\
\mathrm{cm} \text { ) }\end{array}$} & -0.46 & -0.77 & -0.27 & \\
\hline Abate Fetel & & -0.29 & -0.94 & 0.66 & \\
\hline Williams & & -0.38 & 0.14 & -0.15 & \\
\hline P. Triumph & \multirow{3}{*}{$\begin{array}{l}\text { Plant } \\
\text { height } \\
(\mathrm{m})\end{array}$} & -0.21 & -0.22 & -0.20 & 0.72 \\
\hline Abate Fetel & & -0.47 & -0.94 & 0.44 & 0.90 \\
\hline Williams & & $-0.79 *$ & 0.18 & 0.22 & 0.61 \\
\hline
\end{tabular}

*Significant correlation by the t-test, at $5 \%$ probability. both crop seasons. The obtained results are indicative that the quantification of epidemiological and vegetative-reproductive variables is highly important and must also be combined with the evaluation of defoliation intensity, in order to choose the best disease management strategies.

\section{Conclusions}

1. The Abate Fetel and Williams European pear (Pyrus communis) cultivars are the most susceptible and resistant to Entomosporium, respectively.

2. The defoliation onset induced by Entomosporium occurs earlier and at a higher level in the Abate Fetel and Williams cultivars, compared with Packham's Triumph.

3. All cultivars show a negative correlation between defoliation induced by Entomosporium and the vegetative-reproductive variables branch fertility index and plant height.

4. The quantification of epidemiological and vegetative-reproductive variables must be combined with the evaluation of defoliation intensity in order to decide on the most efficient management control.

\section{Acknowledgments}

To Fundação de Amparo à Pesquisa e Inovação do Estado de Santa Catarina (Fapesc) and to Conselho Nacional de Desenvolvimento Científico e Tecnológico (CNPq), for financial support; and to Coordenação de Aperfeiçoamento de Pessoal de Nível Superior (Capes), for student fellowship.

\section{References}

AGRIOS, G.N. Plant pathology. $5^{\text {th }}$ ed. Amsterdam: Elsevier, 2005. 952p. DOI: 10.1016/C2009-0-02037-6.

BELL, R.L.; VAN DER ZWET, T. Host resistance in Pyrus to Fabraea leaf spot. Hortscience, v.40, p.21-23, 2005.

CAMPBELL, C.L.; MADDEN, L.V. Introduction to plant disease epidemiology. New York: J. Wiley\& Sons, 1990. 532p.

CHALLIOL, M.A.; MAY-DE MIO, L.L.; CUQUEL, F.L.; MONTEIRO, L.B.; SERRAT, B.M.; MOTTA, A.C.V.; RIBEIRO JÚNIOR, P.J. Elaboração de escala diagramática para furo-debala e avaliação de doenças foliares em dois sistemas de produção de pessegueiro. Revista Brasileira de Fruticultura, v.28, p.391396, 2006. DOI: 10.1590/S0100-29452006000300012.

FERREIRA, D.F. Sisvar versão 4.2. Lavras: DEX/UFLA, 2003. 
FIORAVANÇO, J.C. A cultura da pereira no Brasil: situação econômica e entraves para o seu crescimento. Informações Econômicas, v.37, p.52-60, 2007.

GONÇALVES, M.J.; BOGO, A.; CASA, R.T.; RUFATO, L.; NICKLIN, J.; BEM, B.P. de; KRETZSCHMAR, A.A.; GRIMALDI, F. Influence of quince rootstocks on Entomosporium leaf spot (Entomosporium mespili) susceptibility in European pear cv. Abate Fetel. Journal of Agricultural Science and Technology B, v.2, p.141-149, 2014. DOI: 10.17265/2161-6264/2014.02B.007.

GONÇALVES, M.J.; BOGO, A.; RUFATO, L.; JESUS JR., W.C. de; CASA, R.T.; WEBER, G.C.; CORREA, D. Behavior of European pear cultivars under different quince rootstocks to 'Entomosporium' leaf spot in southern Brazil. Crop Protection, v.49, p.26-30, 2013. DOI: 10.1016/j.cropro.2013.02.005.

IBGE. Instituto Brasileiro de Geografia e Estatística. Produção agrícola municipal: culturas temporárias e permanentes: 2016. Available at: <https:/www.ibge.gov.br/estatisticas-novoportal/ economicas/agricultura-e-pecuaria/9117-producao-agricolamunicipal-culturas-temporarias-e-permanentes.html? $=\& \mathrm{t}=\mathrm{o}-$ que-e>. Accessed on: Oct. 15 2017a.

IBGE. Instituto Brasileiro de Geografia e Estatística. Produção agrícola municipal: culturas temporárias e permanentes:
2016. Available at: <https://biblioteca.ibge.gov.br/visualizacao/ periodicos/66/pam_2016_v43_br.pdf $>$. Accessed on: Oct. 15 2017 b.

MADDEN, L.V.; HUGHES, G.; VAN DEN BOSCH, F. The study of plant disease epidemics. Saint Paul: APS, 2007. 421p.

NUNES, C.C.; ALVES, S.A.M. Elaboração e validação de escala diagramática para quantificação da severidade de entomosporiose em folhas de pereira. Summa Phytopathologica, v.38, p.239-244, 2012. DOI: $10.1590 / \mathrm{S} 0100-54052012000300011$.

NUNES, C.C.; ALVES, S.A.M.; BOGO, A.; CASA, R.T.; CZERMAINSKI, A.B.C.; SILVA, F.N. da. Optimal conditions for conidial germination and infection of European pear leaves by Diplocarpon mespili. Tropical Plant Pathology, v.41, p.78-83, 2016. DOI: 10.1007/s40858-016-0070-z.

SANTOS, H.G. dos; JACOMINE, P.K.T.; ANJOS, L.H.C. dos; OLIVEIRA, V.A. de; LUMBRERAS, J.F.; COELHO, M.R.; ALMEIDA, J.A. de; CUNHA, T.J.F.; OLIVEIRA, J.B. de. Sistema brasileiro de classificação de solos. 3.ed. rev. e ampl. Brasília: Embrapa, 2013. 353p.

URESK, D.W.; GILBERT, R.O.; RICKARD, W.H. Sampling big sagebrush for phytomass. Journal of Range Management, v.30, p.311-314, 1977. DOI: 10.2307/3897313.

Received on May 16, 2017 and accepted on November 20, 2017 